\title{
Barriers for Students' Learning of Holistic Systems Development
}

\author{
Karin Tweddell Levinsen \\ Department of Educational \\ Anthropology, Danish University \\ School of Education - Aarhus \\ University, Denmark
}

\author{
Sabine Madsen \\ Department of Informatics, \\ Copenhagen Business \\ School, \\ Denmark
}

Kale@dpu.dk

Sma.inf@cbs.dk

\section{Executive Summary}

Based on action research of the Information Processing (IP) course at the bachelor programme HA/DØK at Copenhagen Business School, we investigate which barriers students experience when learning holistic systems development and why. HA/DØK has been developed to educate students who can facilitate between users and programmers and navigate within and between the application (i.e. the users') and the problem (i.e. the IT system's) domain. However, a summative evaluation suggests a gap between the study programme's intention and the students' learning and performance at the IP exam. Our investigation of this gap reveals that while the students readily think and act in accordance with the problem domain they all struggle to achieve the learning objectives that concern the application domain. We propose that the students' difficulties arise as a consequence of how the study programme is designed and outline alternatives for helping them overcome the barriers and/or reach the learning objectives.

Keywords: holistic systems development, systems development methods, bachelor programme, barriers for learning, problem domain, application domain.

\section{Introduction}

In the 1980s it was put forward that integration of the application and problem domain, i.e. the users' area and IT system's tasks respectively, requires that the systems developer possesses particular competences. Until that point in time, systems development had been firmly positioned within the functionalist paradigm, but now a number of new schools and methods, advocated by among others Winston W. Royce, Pelle Ehn, Enid Mumford, Peter Checkland, David Avison, and A.T. Wood-Harper, proposed that the systems developer should have interdisciplinary skills and

Material published as part of this publication, either on-line or in print, is copyrighted by the Informing Science Institute. Permission to make digital or paper copy of part or all of these works for personal or classroom use is granted without fee provided that the copies are not made or distributed for profit or commercial advantage AND that copies 1) bear this notice in full and 2) give the full citation on the first page. It is permissible to abstract these works so long as credit is given. To copy in all other cases or to republish or to post on a server or to redistribute to lists requires specific permission and payment of a fee. Contact Publisher@InformingScience.org to request redistribution permission. be able to move between different paradigms. In other words, the system developer should be able to use, in addition to the functionalist paradigm, the social relativist, the radical structuralist, and the neohumanist paradigms (Hirschheim \& Klein, 1989). Thus, with regard to understanding, communicating, and designing, the 'good' and 'reflective' systems developer is someone who can facilitate between users and 
programmers and navigate easily within and between the application and the problem domain (Curtis, Krasner, \& Iscoe, 1988; Mathiassen \& Purao, 2002).

Already in the mid 1980s the Copenhagen Business School designed a bachelor programme in computer science and economy, called HA/DØK. The purpose of HA/DØK was, and continuous to be, to educate students with competences in holistic systems development, i.e. with competences in facilitating between and integrating the application and problem domain. In Denmark, similar education programmes were later developed at Roskilde University, Århus School of Business, Århus University, and the IT University.

This paper investigates the Information Processing (IP) course, which is located in the fifth semester of HA/DØK. More specifically, the point of departure is the summative evaluation that concluded the course in January 2007 and that puzzled the authors, as well as the students. During a period of four days we held oral exams with 47 students, and therefore 12 groups. While preparing and having the exams we noticed that:

- All students experienced the same problems and barriers irrespective of how they performed at the exam.

- The students' different level of competence influenced if and how they dealt with the problems and barriers.

- The students had a strong tendency to act in accordance with the functionalist paradigm (Hirschheim \& Klein, 1989) when other approaches would have been the natural choice.

We asked ourselves if the observed pattern was a result of: the exam, the IP course in isolation, or of the bachelor programme as a whole. Recently greater attention has been paid to formulation and assessment of learning objectives and outcomes in higher education, i.e. to outcome based academic programmes (Abraham, 2006), but a literature search in relevant databases revealed that so far little research has addressed the relationship between ISD educations' intention, course objectives, and the actual learning outcome. (However, see Cope (2003) and Abraham (2006) for interesting, related studies of learning outcomes in undergraduate ISD programmes). To understand the local problem at the IP course and to contribute to the ISD literature in general, we decided to start an action research collaboration that investigates which barriers students experience when learning holistic systems development and why. We consider the observation of a gap between programme intention, course objectives, and learning outcome as well as our analysis here of to be relevant for ISD education planers, teachers, and organizations that employ students with integrative and facilitator competences.

The paper is structured as follows. First HA/DØK and the IP course are described. Then the research approach is presented. In the next three sections we investigate at what level the gap between intention and learning arises, i.e. at exam, course, and/or study programme level, what the problem is, and what causes it. The concluding section summarises the results and outlines suggestions for helping the students overcome the barriers for learning.

\section{The Case: HA/DØK and Information Processing}

HA/DØK lasts three years distributed over six semesters and covers modules/courses in economy, society, organization, computer science, philosophy of science, IT management, IT law, and a bachelor project. (See Kautz \& Kofoed (2004) for an overview of the study programme and an empirical investigation of first year HA/DØK students' background, experience, and expectations and how these elements influence the teaching and the classroom experience). The progression of the study programme is an increasing focus on IS/IT and on organizational processes, including systems development and other types of change processes. The first four semesters concentrate on 
the solution of well-defined problems via IT, while the fifth and the sixth semesters emphasize problem definitions elicited from ill-structured problem situations, socio-technical solutions, and company collaboration.

Information Processing is located in the study programme's fifth semester within the computer science module. The purpose of the course is to make the students capable of understanding different perspectives on and methods for systems development and of applying them in a practical project. To this end, Information Processing consists of two elements: lectures and project work. The exam is an individual oral exam in both the literature and the project.

The lectures cover Hirschheim \& Klein's four paradigms (1989), the Multiview Methodology (Avison \& Fitzgerald, 2006; Avison \& Wood-Harper, 1990), Soft Systems Methodology (SSM) (Checkland \& Scholes, 1990), Object-Oriented Analysis \& Design (OOAD) (Mathiassen, MunkMadsen, Nielsen, \& Stage, 1997), and principles for user involvement (Mumford, 1995). As the main learning objective of the course is that the students should gain experience with Hirschheim $\&$ Klein's four paradigms, the model will be briefly explained here:

- The functionalist paradigm is the oldest and therefore the classic paradigm. It assumes that the systems developer is a neutral expert who solves a well-defined problem through the use of IT.

- The social relativist paradigm is typical of traditional improvement oriented organizational development. It assumes that the systems developer is a facilitator who helps the case company define and solve a problem situation through understanding and organizational and IT oriented change.

- The radical structuralist paradigm is typical of Scandinavian systems development. It views the systems developer as a partisan who fights for the employees' rights against the employers' demands for e.g. IT driven efficiency gains.

- The neohumanist paradigm is a philosophical inspired ideal. It proposes the systems developer as an emancipator who helps the case company's employees overcome inhibiting convictions and discourses e.g. through IS/IT.

The project work takes place in groups of four in collaboration with case companies. All groups have to hand in a 60 page project structured as follows: introduction, method/empirical data, three analysis sections, process evaluation, conclusion, and appendixes, including documentation of the empirical data. The three analyses sections make up the main part of the project: 1) first the students are to understand the problem situation and identify the need for information systems via SSM, 2) then they perform an object-oriented information analysis (not design), and 3) lastly they use ETHICS to make recommendations concerning the organizational and IT oriented changes that can fulfill the case company's information needs. The projects follow Multiview's first phases as the overall frame and the students shift - more or less consciously - between the social relativist and the functionalist paradigm, while the radical structuralist and the neohumanist paradigms are relevant as inspiration.

The exam takes place as a one hour, individual oral test. The student draws a literature question and has 30 minutes for preparing a presentation on it. The actual exam lasts 30 minutes, with 12.5 minutes for report defense, 12.5 minutes for presentation of the literature question, and 5 minutes for assessment and feedback. The final assessment and grade consists of three parts: a grade given for the group's written report, a grade for the individual oral report defense, and a grade for the individual oral presentation of the literature question. 


\section{Research Approach}

There are many different types of action research (see e.g. Baskerville \& Wood-Harper, 1998). However, the defining features of all action research are intervention into and change of a practical problem situation for the dual purpose of solving the particular problem and contributing to the research literature with new knowledge about the situation, the problem, and its potential solution (McKay \& Marshall, 2001). Action research involves two stages: a diagnostic stage, where the situation is analyzed and an intervention is planned, and a therapeutic stage, where the change experiments take place and the effects are analyzed (Baskerville \& Wood-Harper, 1996). As the action researcher participates actively in the research context action research draws on data collection methods from anthropology and, therefore, also the requirements anthropology poses with regard to source criticism and validity.

Anthropology assumes that as a participant it is not possible to simultaneously observe and document. Data collection can therefore either take place as dynamic, synchronous documentation in the form of video- and sound-recording or as retrospective notes-taking from memory. Whether the retrospective notes are written after the situation or when breaks in the participatory observation allow it depends on the context. Notes from memory are written as detailed thick description (Geertz, 1973). Only as a present, but non-participating, observer is it possible to write synchronous notes via different techniques that in level of detail range from key words to thick descriptions. Neither the synchronous nor the retrospective documentation is objective. In both cases the documentation is a subjectively defined representation of the actual course of events.

We had not originally planned the exam as an action research intervention. However, for the purpose of this paper we will take the liberty of viewing the exam situation as such as a) our purpose is to contribute to both the understanding and solution of the particular problems concerning the Information Processing course and to the ISD literature with more general knowledge about barriers for students learning of holistic systems development, and b) as the phases we have gone through are similar to the two phases of action research. In the diagnostic phase the main concern was how well the students fulfil the learning objectives with regard to understanding and applying the course literature. The learning objectives were operationalized through the choice and design of course literature, project work, and the exam. In the diagnostic phase the course coordinator/examiner had the role of problem owner and action researcher as she created the course structure and, therefore, also the context for the students' (barriers for) learning. In the therapeutic phase the exam was carried out as planned, but the outcome of the intervention was that we started to question the design of the exam, the course, and the study programme. While the exam of course was conducted with a focus on the students' knowledge and level of reflection we jointly started to define a more fundamental problem which we wanted to understand, namely which barriers the students were experiencing in Information Processing and why. As a part of the therapeutic phase we therefore decided to perform a thorough analysis of the problem based on the extensive data material that the exam situation generates. In the therapeutic phase the course coordinator/examiner again had the role of problem owner and action researcher as she was active in creating the situation, and the oral dialogue that constituted the result of the intervention, while censor had the role of present, participating observer as she contributed to the dialogue and to a large extent created the written data material. Due to our joint puzzlement and discussions about the students' difficulties we also both had the role of problem interpreter/solver.

The data material for our analysis can be divided into the following categories:

Before intervention:

- Written material: course description, literature questions, the students' project reports (primarily the sections about method/empirical data and process evaluation). 
- Written notes concerning the students' project reports: examiner's and censor's individual notes about each project report (around 2-4 pages per report containing observations and assessments of the group's work as well as questions for the report defense).

During intervention:

- Thick description written during participatory observation: examiner's notes from the oral exam concerning both the report defense and the literature question, censor's notes from the parts of the oral exam where censor participated in the dialogue with the student.

- Thick description written during present, but non-participating observation: censor's notes concerning the dialogue between the students and the examiner.

- Retrospective notes: notes taken and used to give oral feedback to the groups during assessment, analysis documents concerning our definition of the students' difficulties taken during breaks in the oral exams.

After intervention:

- Retrospective notes: analysis documents concerning our definition of the students' difficulties written shortly after the oral exams, analysis documents concerning examiner's and censor's individual and joint coding of the above mentioned data material.

The course was given to 79 students, and 19 groups. However, this article only uses material about the 47 students and 12 project reports that the authors examined. Thus, the project reports and oral exams that were read and conducted by another examiner and two additional censors are not a part of this study. Throughout this article we will make references to the empirical material. To ensure anonymity we do not use the original group numbers, but have instead recoded the material so that the group numbers range from $1-12$. All direct citations from the empirical material have been translated from Danish by the authors.

Data analysis has been carried out in accordance with the main guidelines for thematic coding of qualitative data: preparation of the data for analysis, reading of parts of or all data material, identification of codes, (re)reading of the data material to ensure that the identified codes are appropriate and sufficient, as well as internal and external validation (Creswell, 2003; Kvale, 1996).

To analyze and ensure continuous internal validation we have chosen systematic reading of all the data material as well as a division of the process, where we first formed an individual and subsequently a common understanding and thematic codes. As preparation for analysis, the censor developed a template that used the project group as the 'research object' and had fields for registering: grade given for the project report (for the entire group), grade given for the report defense (for each student), grade given for the literature question (for each student), citations from the project report, citations from and summaries of examiner's and censor's notes about each project report as well as citations from and summaries of examiner's and censor's notes from the oral exam of each student in the group. Examiner and censor each read all data, filled out the template, and identified potentially relevant themes. The individually identified themes were subsequently discussed in a one-day workshop, where we read and talked through the template data for each group and based on this developed a shared understanding, a written list of main and sub themes, and took notes about our discussions for the later write-up of this paper.

The anthropologic method literature emphasizes that the researcher partakes in the production of the data. When the researchers themselves are participants in the observed context - as is the situation in our case - there is a risk of blind spots and biased interpretations. To ensure external validation we have therefore invited a number of colleagues involved in the HA/DØK study programme to read the article and give feedback. Moreover, censor's detailed, synchronous notes from the role of present, but non-participating observer acts as a guarantee that the examiner 
asked questions in keeping with basic requirements for 'good' qualitative interview technique (Kvale, 1996).

\section{At What Level Does the Problem Arise?}

The research approach's anthropologic roots mean that there are requirements about source criticism and validity of the data material to ensure that the interpretation here of is valid and transparent (Dahler-Larsen, 2002; Kvale, 1996). Therefore, in this section we investigate whether the students' observed difficulties are a result of: 1) the exam and, in particular, our perspective on the exam, 2) the course, and/or 3) the study programme's design and progression.

To be able to separate the three levels analytically we draw on two perspectives to evaluate the students' performance and competences, namely summative and formative evaluation. These were originally formulated by Bloom, Hastings and Madaus (1971) and modernized to the Danish present context by Dahler-Larsen and Krogstrup (2001):

- Summative evaluation: performance and product is assessed in the exam situation based on learning objectives and an official grading scale.

- Formative evaluation: the individual student's learning is continuously evaluated in the teaching situation to ensure further development.

\section{Summative Evaluation}

The summative evaluation takes place by relating the official grading scale to a number of observable phenomena. The grading scale used in this case was the 13-scale as described by the Danish Ministry of Education (see Appendix). The order divides the grades into three groups: good, average, and uncertain. Table 1 shows our concrete operationalizations of the general categories in the 13-scale in the form of groups, grades and learning objectives.

Table 1: Operationalization of learning objectives based on the 13-scale

\begin{tabular}{|c|c|c|}
\hline GROUPS/GRADES & \multicolumn{2}{|c|}{ LEARNING OBJECTIVES } \\
\hline $\begin{array}{l}\text { Good = Grades: } 13,11,10 \\
=\text { Contextual understanding } \\
\text { and demonstration of: }\end{array}$ & $\begin{array}{l}\text { Course literature and project re- } \\
\text { ports: } \\
\text { 1. How systems development } \\
\text { methods and method elements }\end{array}$ & $\begin{array}{l}\text { Project reports: } \\
\text { 1. That the problem definition is } \\
\text { relevant and sufficient given } \\
\text { the context }\end{array}$ \\
\hline $\begin{array}{l}\text { Average }=\text { Grades: } 9,8,7 \\
=\text { Some understanding and } \\
\text { demonstration of: }\end{array}$ & $\begin{array}{l}\text { 2. How well-informed and well- } \\
\text { documented data collection, data } \\
\text { analysis, and user involvement } \\
\text { can be integrated into a systems } \\
\text { development project }\end{array}$ & $\begin{array}{l}\text { 2. That the problem solution is } \\
\text { appropriate given the context } \\
\text { 3. That the individual systems } \\
\text { development methods to a } \\
\text { large extent are applied correct }\end{array}$ \\
\hline $\begin{array}{l}\text { Uncertain = Grades: } 6,5,03 \\
\text { and } 00 \\
=\text { Lack of understanding and } \\
\text { demonstration of: }\end{array}$ & $\begin{array}{l}\text { 3. How the results of the three } \\
\text { analyses can be integrated }\end{array}$ & \\
\hline
\end{tabular}

The assessment of the written project reports, the oral report defenses, and the oral literature presentations produced a distribution as shown in Figure 1. 


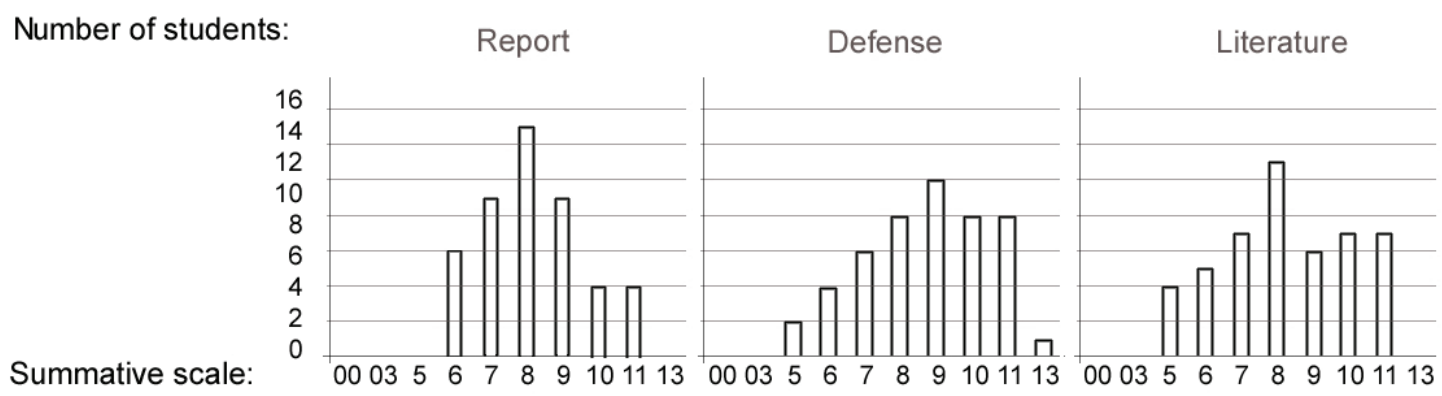

Figure 1: Grades and their distribution

From the project report to the defense and literature presentation a shift can be seen as the middle grade 8 gets a lower representation while the distribution gets broader and the representation in the top of the middle and the top groups are getting stronger. The movements are as follows:

- 25 students got a better grade for the report defense than for the written project report.

- 14 students got the same grade for the report defense and the written project report.

- 8 students got a lower grade for the report defense than for the written project report.

Our notes from the oral exam show that the students that had weak project reports were unable to reflect and engage in a discussion in the exam situation. The students who improved their grade did so by structuring their report defense around the insight that something had gone wrong in their way of integrating literature and practice. Some of these students were, in dialogue with the examiner, able to define what went wrong in their application of the course literature to their company case, while a few students were able to define and discuss the problem on their own. Thus, what we see manifested in the higher grades given for the report defense, and also for the literature presentations, is an after-the-fact reflection.

Our written notes about the students' project reports taken before the oral exam show that the censor had observed the following characteristics: "there is often a lack of methodical considerations about data collection and there is no discussion about data validity. There is a lack of reflection concerning the power and plausibility of the interpretations. Arguments for the (IT) solution are made by drawing on and making references to assumptions and opinions rather than to the application domain and the users. A strong tendency towards consultative user involvement. Weak groups use words such as "we feel that", "we think", and "we believe", or "we have followed the method therefore..." (Censor's notes about the project reports; translated from Danish). The examiner had made similar observations. If it was the case that these observations had guided the exam and the questions asked, the problem that we as examiner and censor identified would have been related to the exam situation and, in particular, our perspective on the exam. However, the improvements in the grades given at the oral exam are a result of the students' own preparation and perspective on the report defense. The students were themselves puzzled by the lack of integration and the contradictions in their use of the course literature and chose to use this puzzlement as a point of departure for the discussion of the report in the exam situation.

This suggests that the problem is not a product of the exam; rather the problem is created somewhere else but becomes observable as a phenomenon in the exam situation. Therefore, it is relevant to investigate if the problem is caused by the learning process the students have gone through before the summative evaluation takes place. 


\section{Formative Evaluation}

The formative evaluation is process oriented and represents changes over time. Dreyfus and Dreyfus's (1986) phenomenological model of skill acquisition shows how learning as a development process might be operationalized as five steps that each describe characteristics of the learner and the learner's approach to a professional practice. What separates Dreyfus \& Dreyfus' five levels from a summative evaluation is that they do not represent a value judgment. Instead the steps constitute a number of necessary, successive phases that the learner has to go through to develop from a novice to an expert in a professional field (see Table 2).

Our problem in relation to an investigation of the students' learning process is that this process was not formally documented while it was taking place. However, two types of data can compensate for this lack of process documentation and still allow for some insight into the learning process: 1) the process evaluations that all groups have written and included in their project reports and 2) the dialogue or lack here of that the examiner was able to establish with the individual student during the oral exam. For both types of data Dreyfus \& Dreyfus' model can be used as a diagnostic tool that can help us understand at which level the students are positioned with regard to learning holistic systems development as a professional practice (see Table 2).

Table 2: Model of skill acquisition and Student behaviour

\begin{tabular}{|c|c|c|}
\hline LEVEL & DREYFUS \& DREYFUS' MODEL & STUDENT BEHAVIOUR \\
\hline $\begin{array}{l}\text { Level 1: } \\
\text { Novice }\end{array}$ & $\begin{array}{l}\text { Little or no previous experience } \\
\text { Does not want to learn; wants to accom- } \\
\text { plish goal } \\
\text { No discretionary judgement } \\
\text { Rigid adherence to rules }\end{array}$ & $\begin{array}{l}\text { Groups } 1,2,8 \text {, and } 10 \\
\text { Group } 10 \text { is prototypical as they: } \\
\text { - Have a lot of empirical data, which they do } \\
\text { not use } \\
\text { - Have no previous experience } \\
\text { - Follow methods exactly as described in the } \\
\text { literature } \\
\text { - Reject the examiner's attempts to create } \\
\text { dialogue during oral exam }\end{array}$ \\
\hline $\begin{array}{l}\text { Level 2: } \\
\text { Advanced } \\
\text { Beginner }\end{array}$ & $\begin{array}{l}\text { Starts trying tasks on one's own } \\
\text { Has difficulty troubleshooting } \\
\text { Wants information fast } \\
\text { Can place some advice in context re- } \\
\text { quired } \\
\text { Uses guidelines, but without holistic un- } \\
\text { derstanding } \\
\text { Develops conceptual models }\end{array}$ & $\begin{array}{l}\text { Groups } 4,5,7,9,11 \text {, and } 12 \\
\text { Group } 5 \text { is prototypical as they: } \\
\text { - Develops conceptual models and under- } \\
\text { stand the formal aspects of the literature } \\
\text { - Still are constrained by rules and unable to } \\
\text { use their empirical data in a holistic way, } \\
\text { i.e. literature wins over empirical data in } \\
\text { situations of uncertainty } \\
\text { - Are puzzled that they have followed a } \\
\text { functionalistic approach because they in- } \\
\text { tended differently }\end{array}$ \\
\hline $\begin{array}{l}\text { Level 3: } \\
\text { Competent }\end{array}$ & $\begin{array}{l}\text { Troubleshoots on one's own } \\
\text { Seeks out expert advice } \\
\text { Sees actions at least partially in terms of } \\
\text { long-term plans and goals }\end{array}$ & $\begin{array}{l}\text { Group 3: } \\
\text { - Identifies problems on their own and seeks } \\
\text { expert advice to move forward with project } \\
\text { work }\end{array}$ \\
\hline $\begin{array}{l}\text { Level 4: } \\
\text { Proficient }\end{array}$ & $\begin{array}{l}\text { Guided by maxims applied to the current } \\
\text { situation } \\
\text { Sees situations holistically } \\
\text { Self-corrects based on previous perform- } \\
\text { ance } \\
\text { Learns from the experience of others } \\
\text { Frustrated by oversimplified information }\end{array}$ & $\begin{array}{l}\text { Group 6: } \\
\text { - Illustrates holistic understanding of local } \\
\text { context } \\
\text { - Draws on previous experience } \\
\text { - Adapts their practice to changing circum- } \\
\text { stances }\end{array}$ \\
\hline
\end{tabular}




\begin{tabular}{|c|c|c|}
\hline $\begin{array}{l}\text { Level 5: } \\
\text { Expert }\end{array}$ & $\begin{array}{l}\text { Does no longer rely on rules, guidelines, } \\
\text { or maxims } \\
\text { Works primarily from intuition } \\
\text { Analytic approaches only used in novel } \\
\text { situations or when problems occur } \\
\text { When forced to follow set rules perform- } \\
\text { ance degrades }\end{array}$ & $\begin{array}{l}\text { One student in Group } 6 \text { explained: } \\
\text { - That soft methods also have characteristics } \\
\text { that promote a functionalistic practice } \\
\text { - How both hard and soft methods can be } \\
\text { combined with user involvement and data } \\
\text { validation to avoid an overly functionalis- } \\
\text { tic approach }\end{array}$ \\
\hline
\end{tabular}

In general the students that were no longer at the novice level questioned the design and progression of HA/DØK. They pointed out that they had not previously been asked to conduct an explorative investigation of the application domain and define real-world problems on their own, as the first two years of the study programme focuses on well-defined problems formulated by teachers, programming, and OOA. One student in particular reached the expert level by questioning the assumptions that the study programme, the course, and the methods are based on.

\section{What is the Problem?}

Even though some of the softer methods also have inherent functionalistic characteristics, we suggest that it is not primarily because of the methods in the course literature that all students think in a certain (IT oriented) way. Rather it seems that when the students enter the IP course they already have a functionalistic preconception of what a problem is, how it should be solved, and how the relationship between the application and the problem domain should be weighed. One student explained that "We are indoctrinated. We think IT" (Group 1, oral report defense, censor's notes). These preconceptions mean that, while the students' performance in relation to the learning objectives that concern system development methods, i.e. learning objectives numbers 1, 3, and 6 (see Table 1) depends on their level of competence, all students struggle to achieve the learning objectives that concern understanding and use of knowledge about the application domain, i.e. learning objectives numbers 2 , 4 , and 5 (see Table 1). The students' difficulties with these three learning objectives are elaborated below.

\section{Empirical Data and User Involvement}

The students' difficulties in achieving this learning objective are manifested in different ways depending on their level of competence: the uncertain students have either not understood the need for and the conceptual distinction between data collection, data analysis, and use of data or their data collection and analysis is very superficial, and often they do not use the data they have in their project work; some students in the middle group are very thorough with regard to data collection and documentation but they are not able to draw on their nuanced understanding of the organizational context in their analyses; while the students in the top group demonstrate thorough collection, analysis, and usage of data. However, some students in the middle and all students in the top group realize that they have collected their data based on a number of assumptions about the problem and its solution; that they need much more data to perform an analysis that is truly based on and driven by the application domain; and that it is necessary to validate their empirical data, interpretations there of, as well as analysis results with the users during the systems development process. In general, the students have not thought about and validated the data and their interpretations, neither internally in the group nor with the users during the process. Moreover, in all cases the user involvement has been consultative (Mumford, 1995) even though many groups have worked with problem situations where it would have been possible, at least to some extent, to conduct consensus oriented user involvement (Mumford, 1995). 


\section{Problem Definition}

When we first read the project reports we quickly discovered that almost all students had decided what the problem was very early on in the project work; that is, at the initial meeting with a contact person - what would normally be considered orientation in the organizational context and not data collection as such. Several groups and students also explained in their process evaluations and/or at the oral exam that they had been very influenced by the contact person's opinions and problem definition. This is illustrated in the following citations: "From the start the group's empirical data collection was influenced by the above mentioned problem definition in the form of a job satisfaction survey instead of a focus on work processes (Group 3, project report, process evaluation) and "We have chosen the manager's perspective. We have not questioned the manager's involvement in everything" (Group 5, oral report defense, examiner's notes). In many cases, the fast problem definition based on the contact person's presentation and interpretations meant that the students did not get a deep understanding of the problem situation and the structures that create it.

\section{Problem Solution}

The fast problem definition and also often its IT solution elicited from the contact person's initial presentation had a profound influence on what type of data the students collected and included in their analyses. One group explains: "Another problem that had a huge impact on our work was that some of the information that we collected early in the process later turned out to be either somewhat deficient or completely incorrect" (Group 6, project report, process evaluation; our translation from Danish). For almost all students, data collection was conducted to confirm and support the already chosen solution rather than to investigate and validate their understanding of the problem and potential solutions. This also meant that it was difficult for them to understand the need for and apply SSM's (Checkland \& Scholes, 1990) and ETHICS's (Mumford, 1995) investigation of alternatives. In general, all groups were very influenced by the contact person's perceptions of the problem situation and its relevant (IT) solution, but some students in the middle and all students in the top group discovered this influence in time to make corrections either in their project reports or in their oral report defense.

The difficulties the students experienced in using application domain knowledge in their project work manifested in different ways depending on their level of competence. However, all students had difficulties applying an explorative approach to the application domain, which meant that their early communication with a contact person and orientation in the organizational context directed their subsequent data collection, problem definition, and solution. Moreover, because they did not validate their data material, interpretations, and analysis results with the users during the process, they did not discover the influence and its consequences for their (lack of) investigation at all or not until very late in the process (e.g. not until the exam).

\section{What Causes the Problem?}

The question is now why it was so difficult for the students to apply an explorative approach to the application domain.

\section{A Problem Domain Mindset}

It is first and foremost difficult for the students to act explorative towards the organizational context because they, in their way of thinking, continuously focus on the problem domain. Thus, in their approach to empirical data, problem definition, and problem solving, they emphasize IT, more specifically a particular IT system, which they have decided is the appropriate solution early 
in the process. Moreover, they are more comfortable in the model world and, even with regard to SSM's rich picture, modeling of the application domain in OOA, and the formulation of objectives and alternatives in ETHICS, the students primarily base their analyses on assumptions and, often, assumptions that the empirical data do not support.

\section{Expert Role}

The students' problem domain mindset and their resulting IT focus and assumption driven analyses mean that they adopt the role of functionalistic experts, cf. Hirshheim and Klein (1989). In other words, they assumed the contact person's perspective, did not involve the users beyond data collection, and believed that they perform and should perform objective analyses. E.g., one group writes that "one of the advantages of SSM is its holistic approach, which ensures an objective analysis" (Group 2, project report, method/empirical data section). During the process and especially at the exam many students realize that they have acted as experts, but even though they are familiar with Hirschheim \& Klein's paradigm model (1989) nearly none of them are at a level were they understand the other perspectives and roles in the model to such an extent that they are able to apply them in practice.

\section{Reflection}

The students' level of competence influences their ability, content, and paradigm of reflection. The uncertain students have difficulties reflecting at all. It is difficult for them to see that their process and product could have been different in both their process evaluation and at the oral defense, which therefore becomes a question-answer session instead of a dialogue. At the middle and top level there is much variation in what the students reflect on. Some students have trouble 'escaping' the problem domain in both the process evaluation and at the oral exam, resulting in a focus on IT and methodical aspects, while others critique the amount and quality of their empirical data and user involvement, thereby engaging in critical reflection on their approach towards the application domain. Some students also realize that they have approached the project work with a particular mindset - a functionalistic predisposition that has made it difficult for them to use different perspectives in the project as the functionalist paradigm emphasizes modeling of the objective reality as an IT-system. Thus, for all students it is the case that their project work has been exclusively functionalistic, which some realize in their process evaluation or at the exam.

The ideal behind the IP course is that the students should engage in holistic systems development where they shift between paradigms by using the application domain and their interpretations here of as the foundation for their methodical analyses, arguments, and decisions and by focusing on socio-technical aspects (and therefore on both the application and problem domain) in their definition of the problem and its solution. However, instead of complying with this ideal, the students apply a functionalistic practice where they use the problem domain and assumptions about this domain as the foundation for their analyses, arguments, and choices. We suggest that the students' 'forgetfulness' of the application domain is due to the fact that before they start the IP course they have gone through the first two years of the study programme, which emphasizes the solving of well-defined problems via IT and pays much less attention to the application domain, explorative method, and empirical data. Thus, when the students enter the IP course they are already proficient functionalists, while they, in relation to the application domain and its relevant methods and considerations, are novices. One could say that Information Processing gives the students the opportunity to go through the first round of the hermeneutic cycle (Gadamer, 2004) and that several more rounds are necessary in order for them to be able to bring an explorative perspective on the application domain into play. It should be noted that many students choose to continue working with explorative methods for organizational and systems development in their 
bachelor projects. It should also be noted that we by no means think that a functionalistic practice, problem domain mindset, and focus on IT should be avoided; rather it should be applied when appropriate during the systems development process.

\section{Conclusion}

Based on action research of the IP course, the purpose of this paper has been to investigate which barriers students in the bachelor programme HA/DØK experience when learning holistic systems development and why. Our analysis shows that the students' performance in relation to the learning objectives that concern system development methods depends on their level of competence, while all students struggle to achieve the learning objectives that are explorative and concern understanding and use of knowledge about the application domain. We conclude that the students' difficulties with a) collection, interpretation, and validation of empirical data, b) formulation of a relevant and adequate problem definition, and c) analyzing several potentially relevant solutions and choosing the best alternative arise because they all think and act in accordance with a) the problem domain, b) the expert role, and c) a more or less exclusively functionalistic approach toward systems development. We suggest that the students' dominant functionalistic practice is due to the fact that, before they enter the study programme's third year and the IP course, they have gone through a curriculum that emphasizes the solving of well-defined problems via IT. Thus, when the students begin the IP course they are already proficient functionalists, while they with regard to the application domain are novices. We conclude that the barriers for the students' learning of holistic systems development come about as a consequence of the course and the study programme's design and progression. It is therefore also at these two levels that the students can be helped to overcome the identified obstacles, e.g. by: a) (re)designing HA/DØK with much more emphasis on the application domain and the relationship between the application and the problem domain much earlier in the programme; b) changing the IP course's learning objectives to reflect that the students first have to realize the consequences of and unlearn their exclusively functionalistic practice before they can begin to learn holistic systems development; and/or c) making it possible for the students to understand consequences and unlearn early in the IP course via exercises and dialogue about the paradigms and their relation to systems development, organizational practice, and empirical data.

\section{References}

Abraham, S. (2006). Assessing the learning outcomes of a computer information systems (CIS) program, Information Systems Education Journal, 4(14). Retrieved from http://isedj.org/4/14/index.html

Avison, D. E., \& Fitzgerald, G. (2006). Information systems development: Methodologies, techniques and tools (4th ed.), Maidenhead, UK: McGraw-Hill.

Avison, D. E., \& Wood-Harper, A. T. (1990). Multiview: An exploration in information systems development, Oxford, UK: Blackwell Scientific Publications.

Baskerville, R., \& Wood-Harper, A. T. (1996). A critical perspective on action research as a method for information systems research, Journal of Information Technology, 11(3), 235-246.

Baskerville, R., \& Wood-Harper, A. T. (1998). Diversity in information systems action research methods, European Journal of Information Systems, 7, 90-107.

Bloom, B. S., Hastings, T. J., \& Madaus, G. F. (1971). Handbook on formative and summative evaluation of student learning. McGraw-Hill.

Bloom, B. S., \& Krathwohl, D. R. (1956). Taxonomy of educational objectives: The classification of educational goals, by a committee of college and university examiners, Handbook I: Cognitive Domain. New York, Longmans, Green. 
Checkland, P., \& Scholes, J. (1990). Soft systems methodology in action. New York, NY, USA: John Wiley $\&$ Sons.

Cope, C. (2003). Educationally critical characteristics of deep approaches to learning about the concept of an information system, Journal of Information Technology Education, 2, 415-427. Retrieved from http://jite.org/documents/Vol2/v2p415-427-122.pdf

Creswell, J. W. (2003). Research design. Qualitative, quantitative and mixed methods approaches, Thousand Oak, CA, USA: Sage Publications.

Curtis, B., Krasner, H., \& Iscoe, N. (1988). A field study of the software design process for large systems. Communications of the ACM, 31(1), 1268-1287.

Dahler-Larsen, P. \& Krogstrup, H. K. (eds.) (2001). Tendenser i evaluering [Trends in Evaluation], Odense Universitetsforlag, DK.

Dahler-Larsen, P. (2002). Fremstilling af kvalitative data [Producing qualitative data], Odense universitetsforlag, DK.

Danish Ministry of Education. (1995). Ministerial Order no. 513 of $22^{\text {nd }}$ of June 1995. Retrieved May 16, 2007 from http://pub.uvm.dk/1999/merkhaand/15.htm\#12.3

Dreyfus, H., \& Dreyfus, S. (1986). Mind over machine: The power of human intuition and expertise in the era of the computer, New York, NY, USA: The Free Press.

Gadamer, H.-G. (2004). Sandhed og Metode [Truth and Method] (original: Wahrheit und Methode, 1960), Viborg: Systime Academic.

Geertz, C. (1973). Deep play: Notes on the Balinese cockfight, in: C. Geertz (ed.), The interpretation of cultures: Selected essays, New York, NY: Basic Books.

Hirschheim, R., \& Klein, H. (1989). Four paradigms of information systems development, Communication of the $A C M, 32(10), 1199-1216$.

Kautz. K., \& Kofoed, U. (2004). Studying computer science in a multidisciplinary degree programme: A freshman students' orientation, knowledge, and background, Journal of Information Technology Education, 3, 227-244. Retrieved from http://jite.org/documents/Vol3/v3p227-244-133.pdf

Kvale, S. (1996). Interviews: An introduction to qualitative research interviewing, Thousand Oaks, CA: Sage Publications.

Mathiassen, L., Munk-Madsen, A., Nielsen, P.A., \& Stage, J. (1997). Objekt-orienteret analyse og design [Object-oriented analysis and design], Forlaget Marko, DK.

Mathiassen, L., \& Purao, S. (2002). Educating reflective systems developers, Information Systems Journal, 12, 81-102.

McKay, J., \& Marshall, P. (2001). The dual imperatives of action research, Information Technology \& People, 14(1), 46-59.

Mumford, E. (1995). Effective systems design and requirements analysis - The ETHICS approach. Basingstoke, UK: Macmillan Press. 


\section{Appendix}

This 13-scale is based on the so called Bloom's taxonomy, which categorizes the cognitive domain of educational objectives, covering the range from simple, unreflected, and factual knowledge to reflected construction of syntheses (Bloom \& Krathwohl, 1956). The scale is elaborately described in the Ministerial Order no. 513 of $22^{\text {nd }}$ of June 1995 by the Danish Ministry of Education. The grades below 6 all imply that the exam is failed, while 6 and beyond means that the exam has been passed. Table 3 provides a summary of the 13 -scale.

\begin{tabular}{|c|c|}
\hline \multicolumn{2}{|r|}{ Table 3: The 13-scale } \\
\hline GRADE & THE STUDENT SHOWS: \\
\hline $\begin{array}{l}\text { Good } \\
13 \\
11 \\
10\end{array}$ & $\begin{array}{l}\text { Extensive and certain knowledge and competences, among other things of concepts and } \\
\text { methods. } \\
\text { Ability to make a clear distinction between important and unimportant aspects. } \\
\text { Ability to include nearly all relevant aspects. } \\
\text { Ability to make arguments for the choice and combination of concepts, methods, and } \\
\text { information in a very certain way. } \\
\text { Ability to make discretionary judgments and generalisations based on concepts, meth- } \\
\text { ods, and information. } \\
\text { Ability to make a very certain application of knowledge and competences to known and } \\
\text { perhaps also to unknown problems. }\end{array}$ \\
\hline $\begin{array}{l}\text { Average } \\
9\end{array}$ & $\begin{array}{l}\text { Broad and fairly certain knowledge and competences, among other things extensive } \\
\text { knowledge about concepts and methods. } \\
\text { Ability to present in such way that important aspects are covered. } \\
\text { Ability to make fairly sufficient arguments for the choice and combination of concepts, } \\
\text { methods, and information. } \\
\text { Ability to make fairly certain judgments and generalisations based on concepts, meth- } \\
\text { ods, and information. } \\
\text { Ability to make a fairly certain application of knowledge and competences to known } \\
\text { problems. }\end{array}$ \\
\hline $\begin{array}{l}\text { Uncertain } \\
6 \\
5 \\
03 \\
00\end{array}$ & $\begin{array}{l}\text { Limited and uncertain knowledge and competences, among other things about concepts } \\
\text { and methods. } \\
\text { Difficulties in distinguishing between important and unimportant aspects. } \\
\text { A lack of ability to include more than a few relevant aspects in presentation. } \\
\text { A lack of ability with regard to making arguments for choices and combining concepts, } \\
\text { methods, and information in a certain way. } \\
\text { A lack of ability in making judgments and generalisations based on concepts, methods, } \\
\text { and information. } \\
\text { A lack of ability in applying knowledge and competences to known problems. }\end{array}$ \\
\hline
\end{tabular}

Source: The ministerial order no. 513 of $22^{\text {nd }}$ of June 1995, the Danish Ministry of Education; our summary and translation from Danish. 


\section{Biographies}

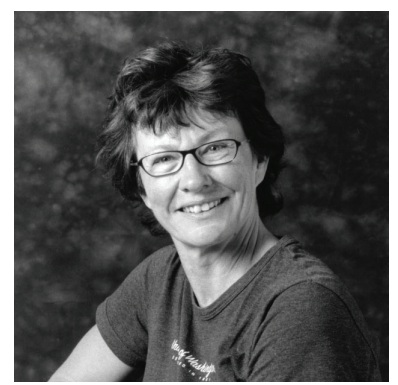

Karin Tweddell Levinsen has a long history of professional experience within the fields of pedagogy, content architecture, interaction design and the transformation of learning objectives and material into design of learning applications for cd-rom and web. She has been authorized external examiner at Danish universities for 10 years. During her professional carrier, she has also conducted research on e-Learning, and has recently, in Nov. 2005, defended her Ph.D. thesis on collaborative online teaching and learning at university level, based on a longitudinal case study of a Danish master programme. She is now Assistant Professor at the Danish University School of Education - Aarhus University. (Photo by Lisbeth Thorlacius).

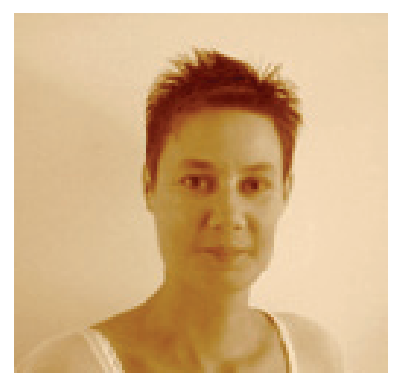

Sabine Madsen is Assistant Professor at the Department of Informatics at Copenhagen Business School, Denmark. She has been employed as a Project Manager in the Danish IT-industry before joining the Department of Informatics in 2001. She completed her Ph.D. about process and method emergence in information system development practice in 2004. Her research interests concern (emergent) IS development processes, methods, and the relationship between research and practice. 